\title{
UVOD
}

\section{STRATEŠKO KOMUNICIRANJE NA VARNOSTNEM PODROČJU}

Na varnostnem, obrambnem in vojaškem področju se nadaljuje ciklično pojavljanje različnih konceptov, povezanih s komuniciranjem. Najnovejši med njimi je strateško komuniciranje, ki sledi konceptom, kot so psihološke operacije, informacijske operacije, javna diplomacija, odnosi z javnostmi, psihološko bojevanje, politično bojevanje in propaganda. V preteklosti so za uresničitev interesov in izpolnitev ciljev različnih držav, mednarodnih organizacij ter drugih udeležencev oblikovali tudi širše koncepte, ki vključujejo različne, s komuniciranjem povezane dejavnosti. Najpomembnejši med njimi, našteti kronološko, so strategija posrednega nastopanja, spopadi nizke intenzivnosti, nevojne vojaške operacije, informacijsko bojevanje, asimetrično vojskovanje, razumna moč in hibridno vojskovanje. Na tem mestu naštetih konceptov ne moremo opredeljevati in primerjati, da bi na podlagi tega lahko določili vzorce (dis)kontinuitete oziroma načine, na katere se ti koncepti podvajajo, prekrivajo in dopolnjujejo. Izhajamo iz dejstva, da je koncept strateškega komuniciranja navzoč tako $\mathrm{v}$ teoriji kot $\mathrm{v}$ praksi različnih udeležencev, zato se bomo v tem uvodu posebne izdaje Sodobnih vojaških izzivov osredinili na konceptualna vprašanja, povezana $s$ strateškim komuniciranjem, in poskušali razpoznati način razumevanja in uporabo tega koncepta v Združenih državah Amerike (ZDA), Ruski federaciji, Evropski uniji (EU), Organizaciji Severnoatlantske pogodbe (Nato) in Islamski državi Iraka in Levanta (ISIL).

Zdi se, da se v sodobni družbi, ki je pogosto označena kot postresnična družba (angl. post-truth society), v kateri čustva, prepričanja in populistična občutja prevladujejo nad dejstvi, podatki in točnimi informacijami (iz slovarja English Oxford Living Dictionaries), pomen strateškega komuniciranja oziroma sorodnih konceptov krepi. Pomembna značilnost postresnične družbe so lažne novice. Poleg tega se zdi, da živimo tudi v družbi vse večjega nezaupanja (angl. posttrust society), $v$ kateri je zaradi upada zaupanja javnosti $v$ institucije uspešno posredovanje sporočil zelo težavno opravilo. Mogoči dejavniki, ki vplivajo na vse 
nižjo raven zaupanja, so družbena odtujenost, pomanjkanje socialnega kapitala, višja raven izobrazbe, večja dostopnost informacij, zaradi katerih je javnost vse bolj dvomeča, večji znanstveni pluralizem, ki vodi do posredovanja dvoumnih sporočil, klientelizem v vladi, porast državljanskega aktivizma, regulatorni škandali in hiperkritičnost medijev (Löfstedt 2005, str. 4). Ciklične gospodarske in finančne krize z negativnimi socialnimi posledicami dodatno otežujejo komunikacijske procese med organizacijami in njihovimi javnostmi.

Koncept strateškega komuniciranja lahko obravnavamo z različnih vidikov: terminološkega, teoretično-konceptualnega, sistemsko-organizacijskega in funkcionalnega. Osredinimo se lahko na primere in izkušnje posameznih držav, njihovih ministrstev za obrambo oziroma oboroženih sil, mednarodnih obrambnih in varnostnih organizacij (koncept, strukture, organiziranost, programi, načrtovanje, vloga političnih odločevalcev in vojaških poveljnikov itn.) ter na empirične analize strateškega komuniciranja oziroma njegovih različnih prvin prek družbenih medijev.

Besedna zveza se je pojavila $\mathrm{v}$ povezavi $\mathrm{z}$ nacionalno strategijo in na področju obrambe ter se je hitro razširila na druga področja, kot so gospodarstvo, odnosi z javnostmi in družbeno komuniciranje. Na splošno strateško komuniciranje pomeni poskus uresničitve glavnih interesov in izpolnitve glavnih ciljev organizacije prek procesa komuniciranja z različnimi javnostmi. Oziroma, kot je to povedal Hallahan s sod. (2007, str. 3), »strateško komuniciranje je namenska uporaba različnih oblik komuniciranja, s pomočjo katerih organizacija izpolnjuje svoje poslanstvo«. Namen strateškega komuniciranja je razumeti, »kako bo določen nabor pogledov, vedenj in zaznav javnosti« podpiral cilje organizacije (Paul 2011, str. 5). Strateško komuniciranje zahteva temeljito in dolgoročno raziskovanje, načrtovanje, izbiro ustreznih medijskih kanalov, nadzor nad komunikacijskim tokom organizacije in posredovanje doslednega sporočila različnim javnostim. Bistvo koncepta je holistično razumevanje različnih oblik komuniciranja, ki jih organizacija uporablja. Po mnenju nekaterih avtorjev je strateško komuniciranje način, na katerega posamezniki in organizacije uporabljajo proces komuniciranja in medije za uveljavljanje svoje vloge $\mathrm{v}$ družbah, ki so pod močnim vplivom medijev (Univerza v Miamiju). Strateško komuniciranje se razvija na področju stikov z javnostmi, vodenja in upravljanja, komuniciranja identitete blagovne znamke in oglaševanja. Uporabljajo ga korporacije, vladne organizacije, mednarodne organizacije, nepridobitne organizacije in celo teroristične skupine. Nedavne vojaške operacije so okrepile naraščajočo moč komuniciranja tako $\mathrm{v}$ javni kot $\mathrm{v}$ politični sferi.

Paul (2011, str. 1) je tudi začel razpravo o vprašanju, kaj strateško komuniciranje je, kaj vključuje in kaj izključuje. Uvedel je več mogočih razlag in definicij strateškega komuniciranja ter njegovih posledic. Čeprav je koncept nejasen, obstaja soglasje, da »sta zaznava in razumevanje podob, politik in ukrepov pomembna, da je uspeh številnih politik odvisen od podpore, ki jo prejmejo od različnih javnosti (tako tujih 
kot domačih) in da na zaznavo vpliva tako to, kar delamo, kot to, kar govorimo« (prav tam). Koncept je izredno pomemben na področju nacionalnovarnostne politike, še zlasti v boju proti nasilnemu ekstremizmu. Ta boj bi se moral ukvarjati $\mathrm{s}$ »prepričanji, motivi in zaznavami, ki temeljijo na ekstremizmu, še posebej s tistimi, ki vodijo k podpori nasilju« (prav tam).

Zdi se, da obstajata dva temeljna razloga za razvoj koncepta strateškega komuniciranja: neučinkovitost komuniciranja od zgoraj navzdol, predvsem v luči sodobne informacijsko-komunikacijske tehnologije, ki državljanom omogoča vključevanje v proces komuniciranja od spodaj navzgor, in pomanjkanje usklajenosti med komunikacijskimi dejavnostmi, bodisi horizontalno ali vertikalno. $\mathrm{V}$ tem duhu se poraja vprašanje, ali ne bi bilo bolje strateškega komuniciranja poimenovati »integrirano komuniciranje« (Westenkirchner 2019).

Ni presenetljivo, da so mednarodni udeleženci koncept strateškega komuniciranja sprejeli in ga začeli razvijati. Guerrero - Castro (2013, str. 27-28) poroča, da so se zmogljivosti strateškega komuniciranja $\mathrm{v}$ ZDA začele pospešeno razvijati po terorističnih napadih 11. septembra 2001: informacijske operacije in psihološke operacije, odnosi z javnostmi in obrambna podpora javni diplomaciji so dobile zagon in začele bojevati »vojno zaznav«. Strateško komuniciranje je bilo kmalu prepoznano kot bistveno za nacionalno varnost ZDA. Njegov namen je pomoč pri doseganju ciljev na področju diplomacije, obrambe, obveščevalne dejavnosti, na področju preprečevanja, odkrivanja in preiskovanja kaznivih dejanj ter na področju domovinske varnosti. Koncept bi morali razumeli kot nadstrankarski, vlada bi morala sodelovati z zasebnim sektorjem, komuniciranje pa bi moralo okrepiti glavne teme in sporočila, »ki bi jih bilo treba ves čas presojati glede na izbrane cilje in jih z njimi usklajevati« (Guerrero - Castro 2013, str. 28).

V krogih ameriške vlade je strateško komuniciranje opredeljeno kot »usmerjena prizadevanja vlade Združenih držav Amerike za poznavanje najpomembnejših javnosti in njihovo vključitev v oblikovanje, krepitev ali ohranjanje razmer, ki so ugodne za podporo interesov, politik in ciljev vlade Združenih držav Amerike, z uporabo programov, načrtov, tem, sporočil in produktov, ki so usklajeni z ukrepi vseh instrumentov nacionalne moči« (Joint Publication 2001).

Nacionalna moč je sestavljena iz gospodarske moči, vojaških zmogljivosti (trda moč), političnega vpliva in kulturnega potenciala oziroma vrednot (mehka moč) države ter predstavlja temelj strateškega komuniciranja. Temeljna zamisel je, da bi lahko strateško komuniciranje učinkovito uporabili pri uveljavljanju nacionalnih interesov z usklajevanjem in poenotenjem informacijske dejavnosti. V poskusu operacionalizacije strateškega komuniciranja je Guerrero - Castro (2013, str. 29) opredelil dva bistvena elementa: usklajevanje besed in dejanj (in kako jih izbrana javnost zaznava) ter programe in dejavnosti, vključno s tistimi, ki jih izvajajo strokovnjaki s področja odnosov z javnostmi, javne diplomacije in informacijskih operacij, ki so usmerjeni h komuniciranju in sodelovanju z izbrano javnostjo. 
Ruska federacija je razvila strateško komuniciranje, ki je kompleksno tako z vidika idej, ki jih promovira, kot z vidika vključenih institucij. Na tem področju je zelo dejavna in razmeroma učinkovita $v$ ZDA, državah članicah EU, republikah nekdanje Sovjetske zveze in v državah kandidatkah za članstvo v EU. Uspeh Ruske federacije je še dodatno okrepila gospodarska kriza, ki je prizadela in celo marginalizirala različne družbene skupine $\mathrm{v}$ omenjenih državah. Tudi vloge migrantske krize $\mathrm{v}$ Evropi v obdobju 2015-2016 in v ZDA pri tem ne smemo podcenjevati. Vsebina ruskega strateškega komuniciranja ni nujno vedno dosledna, vendar $» j e$ njegovo izvajanje sofisticirano, ciljno usmerjeno in prilagojeno različnim javnostim« (Directorate General for External Policies 2016, str. 6). Sposobno je izkoristiti pomanjkljivosti in napake nasprotnikov. Glavni namen strateškega komuniciranja je razvijanje in uveljavljanje mehke moči Ruske federacije. Promocija države in njenih politik poteka prek medijev (najpomembnejša sta Russia Today in Sputnik News), nevladnih organizacij, gospodarskih lobijev, političnih strank in drugih udeležencev. Če razmere niso naklonjene poudarjanju uspehov Ruske federacije, postane glavna naloga strateškega komuniciranja usmerjanje toka negativnih novic o zunanjem svetu: Zahod je prikazan kot nasilen in osvajalen subjekt, ki je šibek in se bo najverjetneje zrušil, EU bo razpadla zaradi finančne in migrantske krize in bo doživela podobno usodo kot nekdanja Sovjetska zveza (Directorate General for External Policies 2016, str. 9). Za krepitev argumentov Ruske federacije proti Zahodu oziroma EU, ZDA in Natu se pogosto uporablja teorija zarote. Slabosti EU, kot so Brexit, neučinkovito in zamudno reševanje migrantske krize, zapleteni postopki sprejemanja odločitev, populizem in podobno so v zadnjih letih prispevali k uspehu strateškega komuniciranja Ruske federacije.

Nato je na področju komuniciranja poudarjeno dejaven vse od leta 1950, ko je bila ustanovljena Natova služba za informiranje (NATO Information Service, NATIS), razvoj njegovega koncepta strateškega komuniciranja je dobil zagon po ruski priključitvi Krima marca 2014. Takratni vrhovni poveljnik zavezniških sil Nata je dogodek označil kot »najbolj izjemno bliskovito vojno (blietzkrieg), ki smo ji bili kadar koli priča v zgodovini informacijskega bojevanja« (Directorate General for External Policies 2016, str. 18).

Natova politika komuniciranja strateško komuniciranje opredeljuje kot »usklajeno in ustrezno uporabo Natovih komunikacijskih dejavnosti in zmogljivosti - javne diplomacije, vojaških odnosov z javnostmi, informacijskih operacij in psiholoških operacij - da podpre politike, operacije in dejavnosti zavezništva in da promovira Natove cilje« (International Staff 2009). Glavni namen strateškega komuniciranja je torej podpiranje in krepitev Natovih prizadevanj, da bi dosegel svoje politične in vojaške cilje. Strateško komuniciranje na predhodno omenjenih področjih bi moralo prispevati k uspešni izvedbi Natovih operacij, misij in dejavnosti, oblikovanju javnega zavedanja o pomenu Nata, razumevanju in podpori njegovim specifičnim politikam, operacijam in drugim dejavnostim pri različnih javnostih ter k boljšemu razumevanju Nata med splošno javnostjo. Pri strateškem komuniciranju ne gre za 
ločen organ ali organizacijo, temveč za sestavni del načrtovanja zavezništva od zgodnjih stopenj naprej.

Kljub temu so januarja 2014 ustanovili Natov center odličnosti za strateško komuniciranje (NATO Strategic Communications Centre for Excellence, StratCom CoE), v katerem delujejo pripadniki, ki prihajajo iz civilnega, vojaškega, zasebnega in akademskega sektorja. Namen centra je podpiranje cele vrste Natovih procesov komuniciranja, njegove glavne dejavnosti pa lahko povzamemo kot razvijanje politike komuniciranja in njene promocije prek Natovih teles in poveljstev, raziskovanje scenarijev hibridnega vojskovanja in informacijskega bojevanja Ruske federacije, ISIL-a in drugih vpletenih, izobraževanje na področju komuniciranja in publicistična dejavnost (npr. izdajanje revije Defence Strategic Communications) (Directorate General for External Policies 2016, str. 19).

Po mnenju nekaterih avtorjev (npr. Wilburja 2017, str. 209) strateško komuniciranje uporabljajo tudi ekstremistične skupine, med katerimi so teroristi. Njegova analiza se nanaša na uporabo propagande kot oblike strateškega komuniciranja ISIL-a. $\mathrm{S}$ tehničnega vidika je ISIL strateško komuniciranje uporabljal podobno kot neekstremistične organizacije, torej tako, da je »svojo organizacijo promoviral kot boljšo od konkurenčnih«. Po ugotovitvah analitikov Oddelka za oblikovanje politike, ki deluje v Generalnem direktoratu za zunanjo politiko EU, je ISIL prek revij in videov ter $\mathrm{z}$ učinkovito uporabo družbenih medijev ponovno opredelil način pošiljanja političnih sporočil različnim javnostim, ki vključujejo vse od mednarodnih nasprotnikov do dejavnih članov ISIL-a in morebitnih novih članov (Directorate General for External Policies 2016, str. 20). Strateško komuniciranje ISIL-a je bilo oblikovano za doseganje dolgoročnega političnega cilja organizacije: zagotavljanje njenega preživetja in zavzetje čim večjega fizičnega in virtualnega prostora. Namen strateškega komuniciranja ISIL-a je bil predstaviti ga kot učinkovito vojaško in politično organizacijo, ki je sposobna voditi kalifat, novačiti nove člane in jih zadržati, razložiti svoj obstoj ter vcepiti strah v družbe nasprotnikov in jih razdvojiti. Proces posredovanja sporočil različnim javnostim je bil dosleden in strateški (prav tam). Na srečo se je pokazalo, da so bili cilji ISIL-a preveč visokoleteči.

V svoji analizi je J. Reid (2018, str. 52) posredno opozorila, da je zelo pomembna tudi obramba pred negativnim strateškim komuniciranjem. Raziskovala je »negativne informacijske kampanje«, ki jih je Ruska federacija izvajala ob priključitvi Krima in med oboroženimi spopadi v Donecku in Lugansku. Poglobila se je tudi v nedavni ruski vdor v družbene medije ZDA. Po avtoričinem mnenju je prebivalstvo držav Srednje in Vzhodne Evrope še posebno podvrženo negativnim sporočilom Ruske federacije in celo različnih terorističnih skupin. Raziskava je posebno zanimiva, ker odkriva kulturno podlago moči, tekmovalnosti, individualizma, negotovosti, izogibanja, dolgoročnega usmerjanja in popuščanja v kontekstu dojemljivosti za negativne vplive. 
V duhu odgovora na negativno strateško komuniciranje je EU pred kratkim razvila svoj koncept strateškega komuniciranja, in to kljub dejstvu, da so države članice na tem področju dolgo časa želele delovati samostojno. Za poglobljeno obravnavo informacijskih groženj $\mathrm{v}$ kontekstu strateškega komuniciranja se je oblikovala medsektorska politika EU, ki se osredinja na preplet vrednot in ciljne javnosti (Örden 2019, str. 421). Glavni razlog, da so države članice sprejele usklajena prizadevanja na tem področju, so bile prej omenjene nedavne dejavnosti Ruske federacije in Islamske države Iraka in Levanta, ki sta bila vpletena v »agresivno pošiljanje sporočil in zavajajoče medijske kampanje (Directorate General for External Policies 2016, str. 4). Za spopadanje s tem so ustanovili Sektor za strateško komuniciranje (Strategic Communication Division), ki tesno sodeluje z Evropsko službo za zunanje delovanje (European External Action Service, EEAS) in institucijami EU. Sektor jim zagotavlja smernice in podporo glede komuniciranja ter tako podpira glavne politike in temeljne vrednote EU. Med drugim so za obravnavo širjenja dezinformacij Ruske federacije oblikovali tudi projektno skupino EU East StratCom (East StratCom Task Force). Njene naloge so promocija sosedske politike EU na vzhodu, krepitev medijskega okolja, zlasti svobode in neodvisnosti medijev, ter odgovor na dejavnosti zunanjih udeležencev, povezanih s širjenjem dezinformacij. Projektna skupina se ne ukvarja s protipropagando, temveč le prepoznava in razkriva dezinformacije. Prav tako projektna skupina ni usmerjena proti »propagandistom « - osredinja se na sporočilo, in ne na prenašalca sporočila (Strategic Communications 2019). Vloga in naloge projektne skupine so podrobno opredeljene v Akcijskem načrtu EU za strateško komuniciranje, sprejetem junija 2015 (EU's Action Plan on Strategic Communication 2015).

Končujemo z Guerrero - Castrom (2013, str. 30), ki je o konceptu strateškega komuniciranja postavil več vprašanj. Ali se koncept nanaša na odnose z javnostmi, novinarstvo, diplomacijo, telekomunikacije, propagando oziroma prizadevanja za oblikovanje podobe države? Ali se nanaša na usklajevaje notranjega in zunanjega komuniciranja javnih, državnih in vladnih institucij? Ali gre v bistvu za oglaševanje organizacije? Kakšno vrsto strateškega komuniciranja naj bi uporabljali za doseganje nacionalnih interesov? Avtor hkrati opozarja, da obstaja toliko različnih definicij strateškega komuniciranja na tako veliko družbenih področjih, da je koncept izgubljen »v vesolju dvoumnosti, zmed in konceptualnih vrzeli« (prav tam). Morda bo prav ta posebna številka Sodobnih vojaških izzivov odgovorila na nekaj izmed teh vprašanj in pripomogla $\mathrm{k}$ pojasnitvi koncepta strateškega komuniciranja. 
Literatura

1. Directorate General for External Policies. Policy Department. 2016. EU strategic communications with a view to countering propaganda. European Union.

2. English Oxford Dictionaries. https://en.oxforddictionaries.com/definition/post-truth. [Accessed 22 Mar. 2019].

3. EU's Action Plan on Strategic Communication. 2015. Ref. Ares 2608242 - 22/06/2015.

4. Guerrero-Castro, C. E., 2013. Strategic Communication for Security \& National Defense: Proposal for an Interdisciplinary Approach. Connections: The Quarterly Journal 12: 2, pp 27-51.

5. Hallahan, K.; Holtzhausen, D.; van Ruler, B.; Vercic, D. and Sriramesh, K., 2007. Defining strategic communication. International Journal of Strategic Communication 1: 1 , pp 3-35.

6. International Staff. 2009. NATO Strategic Communication Policy. SG(2009)0794).

7. Joint Publication 1-02. Department of Defense Dictionary of Military and Associated Terms, Washington D.C., 12 April 2001/as amended through 17 March 2009/.

8. Löfstedt, R. E., 2005. . Houndmills and New York: Palgrave Macmillan.

9. Miami University: Strategic Communication. https://miamioh.edu/academics/majorsminors/majors/strategic-communication.html [Accessed 22 Mar. 2019].

10. Örden, H., 2019. Deferring substance: EU policy and the information threat6. Intelligence and National Security. Published online 12 Feb 2019, pp 421-437.

11. Paul, C., 2011. . Santa Barbara: Praeger.

12. Reid, J., 2018. Defense against Negative Strategic Communication. Connections: The Quarterly Journal 17: 3, pp 52-60.

13. Strategic Communications. https://eeas.europa.eu/headquarters/headquarters-homepage en $/ 2116 / \% 20$ Questions $\% 20$ and $\% 20$ Answers $\% 20$ about $\% 20$ the $\% 20$ East $\% 20$ StratCom\% $\% 20$ Task\%20Force) [Accessed 25 Mar. 2019].

14. Westenkirchner, P. E., 2019. Framework Concept Integrated Communication in Multinational Coalition Operations within a Comprehensive Approach. https:// en.wikipedia.org/wiki/Strategic_communication\#tite_note-6 [Accessed 21 Mar. 2019].

15. Wilbur, D., 2017. Propaganda's Place in Strategic Communication: The Case of ISIL's Dabiq Magazine. International Journal of Strategic Communication, 11: 3, 209-223. 
